\title{
MOLNÁR-TAMUS VIKTÓRIA
}

föiskolai docens

Debreceni Református Hittudományi Egyetem

Pedagógia és Pszichológia Tanszék

molnar.tamus.viktoria@drhe.hu

\section{TUDOMÁNY ÉS MÜVÉSZET EGYÜTTES JELENLÉTE PUKÁNSZKY BÉLA PROFESSZOR (1895-1950) ÉLETPÁLYÁJÁN}

A debreceni egyetem bölcsészettudományi kara történetének elsö korszakában több oktató is szoros kapcsolatban állt a müvészetekkel. Ez a tanulmány elsösorban a pozsonyi kötödésü Pukánszky Béla professzor zenei jelentöségét kivánja bemutatni. A kutatás során próbáltam a személyes hagyatékok fennmaradt iratait, illetve a kortárs tudóstársak, kollégák által irt kritikákat, recenziókat és jubileumi tanulmányokat elolvasni és feldolgozni. Pukánszky Béla esetében a Debreceni Egyetem Kézirattárában fennmaradt dokumentumokra (jegyzökönyvek, hangverseny-meghivók, kézirásos és gépelt szövegü zenetörténeti elöadások), azon belül is elsösorban felesége levelezésére támaszkodtam. Ezek eredményeként beszámolok Pukánszky Béla müvészetekkel foglalkozó tudományos és ismeretterjesztö irói, illetve elöadói tevékenységéröl, hogy milyen aktiv szerepet vállalt Debrecen és Budapest, tulajdonképpen egész Magyarország müvészeti közéletében. Kutatásom eredménye így a debreceni egyetemi bölcsészkar, valamint a város országos szinten is kiemelkedö értelmiségi köreinek jelentös müvelödéstörténeti, kulturális ismeretterjesztési és müvészetpártolói ténykedésének eddigi eredményeit gazdagitja.

Kulcsszavak: Debreceni Egyetem, Bölcsészkar, Pukánszky Béla (1895-1950), zeneművészet és -történet, tudományos írások, ismeretterjesztő előadások

The Combined Presence of SCIEnCE and ARt in the Career of Professor Béla PukÁnszky (18951950). In the first phase of the history of the Faculty of Humanities, University of Debrecen, several lecturers were in close connection with arts. This study intends to introduce primarily the musical significance of Professor Béla Pukanszky from Pozsony. In the course of the research, I attempted to read and process the surviving documents of the personal legacy along with the critiques, reviews and jubilee studies written by contemporary scholars and colleagues. In Béla Pukanszky's case, I relied on the documents preserved in the Manuscript Archive at the University of Debrecen (minutes, concert invitations, handwritten and typed music history performances), and especially on his wifés correspondence. As a result, I report on Béla

Beérkezett: 2021. 08. 15.

Közlésre elfogadva: 2021. 10. 15.

Copyright GERUNDIUM 
Pukanszky's art-related scholarly and educational pursuits as writer and lecturer, and demonstrate the proactive role he undertook in the artistic life of Debrecen, Budapest, and the whole of Hungary. Thus, my work contributes to the previous research results on the important activities of the faculty's and the town's nationally outstanding intellectual circles in the fields of cultural history, cultural education and art patronage.

Keywords: University of Debrecen, Faculty of Humanities, Béla Pukánszky (1895-1950), music and history of music, scholarly studies, outreach lectures

Ebben a tanulmányban néhai Pukánszky Béla (1895-1950) debreceni professzor munkásságára fókuszálok. ${ }^{1}$ Szeretném ebből is a szorosan vett zenetörténeti és előadói tevékenységét feltárni, hogy milyen közéleti fórumokon, eseményeken mutatta be zenei érdeklődésének és tanulmányainak eredményeit. Hogyan is vált Pukánszky Béla kutatásom tárgyává?

A debreceni egyetem bölcsészettudományi karának első korszakában - 1914-1949 több oktató is szoros kapcsolatban állt a művészetekkel. Ez az írás elsősorban a pozsonyi kötődésű Pukánszky Béla professzor zenei jelentőségét kívánja bemutatni, ami része a 2017-ben, a Debreceni Egyetem Humán Tudományok Doktori Iskolájában megvédett doktori (PhD) disszertációmnak. ${ }^{2}$ Ennek fó célkitűzése a Debreceni Egyetem Bölcsészkara oktatóinak a tanári hivatása során végzett művészeti, művészetpártolói, valamint közéleti tevékenységének a feltárása és elemzése volt az egyetem történetének első periódusában. Alapvetően a Debreceni Tudományegyetem Bölcsészettudományi Karának tanszékein 1914 és 1949 között tanító professzorok és tanárok művészeti-alkotó, művészetelméleti-oktató és művészettámogató-pártoló tevékenységének jelentőségéről adok számot az értekezésben, melyben végső soron annak bemutatására vállalkoztam, hogy milyen sokrétű művészeti tevékenységet folytattak a 20. század első felében a debreceni egyetem bölcsészettudományi karának oktatói tudományos feladatvégzésük mellett. Ennek megfelelően összesen 18 bölcsésztanári életpályát elemeztem a művészet elméleti és gyakorlati oldaláról közelítve, s ezek egyike Pukánszky Béla pályafutása, akiről elsősorban a Debreceni Egyetem Kézirattárában fennmaradt dokumentumokból (egyetemi évkönyvek, jegyzőkönyvek, hangverseny-meghívók, kézírásos és gépelt szövegü zenetörténeti előadások), azon belül is elsősorban felesége levelezéséből nyertem információkat.

\footnotetext{
${ }^{1}$ A kutatás támogatója a Debreceni Református Hittudományi Egyetem kutatás-finanszírozási pályázata volt.

2 Tamusné Molnár Viktória, Müvészeti nevelés az egyetem falai között és azon túl. A debreceni egyetem bölcsészettudományi kara oktatóinak müvészeti, müvészetelméleti és müvészetpártolói tevékenysége 1914-1949. Doktori (PhD) értekezés. DE BTK Humán Tudományok Doktori Iskolája, Debrecen, 2016. https:// dea.lib.unideb.hu/dea/bitstream/handle/2437/236622/Tamusne_Molnar_Viktoria_ertekezes_2016_ titkositott.pdf?sequence=1\&isAllowed=y. Hozzáfárás: 2021 10. 29.
} 


\section{A zenei közélet eseményei Pukánszky Béla életútjának állomásain}

Pukánszky Béla (1895. december 22., Pozsony-1950. október 26., Budapest) irodalomtörténész, művelődés- és zenetörténész, egyetemi tanár. Édesapja Pukánszky Béla (1859-1899) teológus, a pozsonyi teológiai akadémia rendes tanára. A korai árvaházi évek után ${ }^{3}$ a pozsonyi evangélikus líceumban tanult. ${ }^{4}$ Érettségi után színész, karmester vagy hegedűvirtuóz szeretett volna lenni, ám ez meghiúsult gyámja, Kovács Sándor evangélikus püspök konzervatív felfogása, illetve fösvénysége miatt. Az Eötvös Kollégium tagjaként - ahová sikerült bejutnia egy ingyenes helyre - a Budapesti Tudományegyetemen 1918-ban bölcsészdoktori oklevelet, egy év múlva magyar-német szakos középiskolai tanári oklevelet, majd 1927-ben német irodalomtörténet tárgykörben magántanári képesítést szerzett. 1932-ben a Magyar Tudományos Akadémia tagja lett. 1920 és 1927 között a Budapesti Tudományegyetem Közgazdaságtudományi Karán német nyelvi lektor, ezt követően a Pázmány Péter Tudományegyetemen és a Budapesti Tanárképző Intézetben a német irodalomtörténet tanára 1941-ig. 1940 és 1945 között a Magyar-Német Társaság Művészeti Bizottságának elnöke, az utolsó évben pedig az igazgatótanács tagja. Thienemann Tivadarral együtt szerkesztette a Pázmány Péter Tudományegyetem Német Intézetének Irodalomtudományi Évkönyvét 1936-tól 1938-ig, valamint az Ungarn címủ folyóiratnak volt a szerkesztője 1941 és 1944 között. ${ }^{5}$

A Debreceni Egyetem tanára 1941-től haláláig volt, ${ }^{6}$ vezette a Német Tanszéket, közben a Bölcsészet-, Nyelv- és Történettudományi Kar dékánja (1947/1948), a következő évben rektora volt. Irodalmi és nyelvészeti főkollégiumok mellett német nyelvi gyakorlatokat tartott. ${ }^{7}$ Főleg magyarországi német irodalom- és művelődéstörténettel, a magyar-német irodalmi, művelődéstörténeti és zenei kapcsolatok történetével, valamint általános magyar irodalomtörténeti kérdésekkel foglalkozott. ${ }^{8}$

3 1899-től 1905-ig a pozsonyi pietista árvaházban nevelkedett.

${ }^{4}$ A Pozsonyi Ágostai Hitvallású Evangélikus Liceum Értesitöje (Pozsony: Wiegand, 1907), 103. https:// adt.arcanum.com/hu/view/Pozsony_28452_evangelikus_foiskola_28500_1907/?pg=668layout =s. Hozzáférés: 2021. 12. 20.; A Pozsonyi Ágostai Hitvallású Evangélikus Liceum Értesitóje (Pozsony: Wiegand, 1910), 100. https://adt.arcanum.com/hu/view/Pozsony_28452_evangelikus_foiskola_285 03_1910/?pg=0\&layout=s. Hozzáférés: 2021. 12. 20.

${ }^{5}$ Némedi Lajos, Béla Pukánszky (1895-1950). Különlenyomat a debreceni Kossuth Lajos Tudományegyetem Germanisztikai Intézetének kiadványaiból: „Német Filológia Tanulmányok” 1964. (Budapest: Tankönyvkiadó, 1964).

${ }^{6}$ Oktatott tárgyai: A német irodalomtörténet áttekintése (I. Középkor, II. A reformáció kora, III. A barokk költészet, IV. A felvilágosodás, V. Az irracionalizmus, VI. A klasszicizmus, VII. A romantika, VIII. Realizmus, IX. A XIX. század második fele); Történeti német nyelvtan; Rainer Maria Rilke, Gerhart Hauptmann, Thomas Mann és A német impresszionizmus és szimbolizmus, A mai német irodalom föirányai, valamint Német szemináriumi gyakorlatok. Vö. A debreceni tudományegyetem tanrendjei, 1914-1949.

7 Mudrák József. A Debreceni Tudományegyetem Bölcsészettudományi Karának története (1914-1949) (Debrecen: Egyetemi Kiadó, 2012).

${ }^{8}$ KozÁk Péter. Pályakép, 2013. www.nevpont.hu/view/7104. Letöltés: 2016. december 20. http://www. nevpont.hu/palyakep/pukanszky-bela-2be83. Hozzáférés: 2021. 10. 29. 
Mint elismert irodalomtörténész nagyfokú művészeti, elsősorban zenei érdeklődést mutatott. Felesége, Pukánszky Béláné Kádár Jolán visszaemlékezése szerint ez még gyermekkorából eredt. A zenei hajlamot zongorista édesanyjától hozta. A pozsonyi pietista árvaházban a gyermekkórusban énekelte Bach kantátáit. Hegedülni szülővárosában kezdett, majd Pesten folytatta, ahol tanára Waldbauer József volt. ${ }^{10}$ A Magyar Rádióban kb. 40 ismeretterjesztő előadása hangzott el a zenetörténet legkülönbözőbb korszakairól és zeneszerzőiről. ${ }^{11}$ Gimnazista kora óta remek előadói vénával rendelkezett. Ahogyan az életrajz elején említettem már, rajongott a színészetért és aktív színházlátogató volt; előadóként, versmondóként vagy hegedűsként rendszeres fellépője az iskolai ünnepi alkalmaknak - nemcsak élvezője és elméleti méltatója a zenének, hanem folyamatos művelője. Több kamaraegyüttesben játszott már egyetemistaként ('́gy Kastner Jenővel s a később külföldön nagy sikereket aratott Ember Nándorral). Eckhardt Sándorral sokat szonátázott, triójukban Heller Farkas zongorázott, egyik hangszernégyesében pedig Scholz János, később a világhírủ Roth kvartett tagja volt a csellista. A kitűnő zongoraművésznő, Kresz Gézáné Drewett Nóra zongoraszólamával időnként kvintetté bővültek. Uray Magdolnával Debrecenben szonátázott sokat, ahol Gosztonyi Béla MÁV ügyeletigazgatóval, Eisler Géza bőrgyógyásszal és Hahn György szemorvossal kvartettje volt. Később zongorahármasban és -négyesben is részt vett, egyszer nyilvánosan is felléptek jótékony céllal. ${ }^{12}$

Itthon és külföldön egyaránt tartott művészeti tárgyú előadásokat, több mint százat. Az Operaház színpadán érte a legnagyobb siker a Varázsfuvola ünnepi előadása előtt tartott bevezetőjével 1942-ben. ${ }^{13} \mathrm{Az}$ új magyar zene címmel jelent meg egy tanulmánya a Budapesti Szemleben ugyancsak ebben az esztendőben. Kora friss műveinek és zeneszerzőinek bemutatása mellett értékelte az aktuális komolyzenei törekvéseket és modern próbálkozásokat. ${ }^{14}$ Komolyzenei témákban további tanulmányai is születtek, pl. Buda és Pest zenei művelődéséről, az irodalom és a zene nagyjainak kapcsolatáról. ${ }^{15}$ Híres szerzők - Mozart, Wagner, Bartók és Kodály - zeneműveit elemezte egyes írásaiban. ${ }^{16}$

9 Pukánszky Béláné Kádár Jolán országos főlevéltárnok volt. A nemzeti színészet története a magyar művelődés keretében című tárgykörben habilitált 1947-ben a debreceni egyetem magyar irodalomtörténeti tanszékén, a 19. század első felének színjátszásáról tartott előadásokat, és férje után ő is bekapcsolódott az egyetem bölcsésztanárainak művészeteket népszerűsítő tevékenységébe. Vö. Mudrák, A Debreceni Tudományegyetem Bölcsészettudományi Karának története.

${ }_{10}$ Pukánszky Béláné, Kádár Jolán levélváltása Némedi Lajossal (1964). DE ENK BTK és TTK Kt. kgy. Ms. 29.

11 PUKÁNsZKY Béla-anyag. DEENK BTK és TTK Kt. kgy, 37/1959. Ms 29. 1959. október 26.

12 Némedi, Béla Pukánszky.

13 PukÁnszKY Béla-anyag.

${ }_{14}$ Pukánszky Béla, „Az új magyar zene”, Budapesti Szemle 70. (1942): 36-52.

15 Pukánszky Béla-anyag; Pukánszky Béla, Beethoven és Goethe. Debreceni Egyetem Egyetemi és Nemzeti Könyvtár Bölcsészettudományi és Természettudományi Kézirattári különgyűjteménye (a továbbiakban: DE ENK BTK és TTK Kt. kgy.) Ms. 29/39g/2; PukÁnszky Béla, Beethoven és Kant. DE ENK BTK És TTK KT. kgy. Ms. 29/39g/1.

16 PukáNszky Béla, „Bartók Béla. Töredék egy készülő tanulmányból”, Vándortüz 6. (1947): 60-62. 
„A zene számára mindig tudott időt szakítani. Lelkes operalátogató és Wagnerrajongó volt, sokat járt hangversenyekre, lelkes propagátora volt a modern magyar zenének, őtőle indult ki Bartók Béla ajánlása az akadémiai tagságra, művészetét több előadásban méltatta. Kapcsolatuk még gyermekkorában, Pozsonyban kezdődött. (L. Emlékek Bartók Béláról c. posthumus cikkét az Alföld 1956. évfolyamában.) Az ő javaslatára adták 1940-ben a Weiss Fülöp jutalmat megosztva Bartók Cantata profanajának és Kodály Budavári Te Deumának (L. idevágó jelentését az Akadémiai Értesítőben). Kodályt az Eötvös Kollégiumból ismerte. Mưvészetét többször méltatta. (A hatvanéves Kodály Zoltán Bp. Szemle)”17

Az 1946-47-ben rendezett 20 hangversenyből álló zenetörténeti sorozatba illeszkedő Ady Társaság-beli, ${ }^{18}$ a debreceni zeneiskola nagytermében elhangzó zenetörténeti hangversenyeken bevezető előadásokat tartott. A legjobb értelemben vett ismeretterjesztést szolgálta e kamarajellegủ esteken megnyilvánuló zeneszeretete és kiváló előadókészsége. ${ }^{19}$

Az 1947-ben, Bartókról írt tanulmánya jól illeszkedett a debreceni Ady Társaság azon művészeti törekvéseihez, melyek nagyban hozzájárultak a Bartók (és Kodály) kultusz népszerüsítéséhez. ${ }^{20}$

A debreceni Csokonai Színház 1947-48. évadbeli Háry János-előadása elégedetlenséget ébresztett Pukánszkyban a közönséggel kapcsolatban. A recenzióban így írt erről:
„A hallgatóság tehetős része Kodály zeneszámait végigfecsegte, mintha kávéházi muzsika mellett szórakozna. Mennyivel fogékonyabb magatartást tanúsított a karzat egyszerü közönsége, ezzel is figyelmeztetve az illetékeseket arra, hogy ez a közönség a legjobb nevelést és a legjobb produkciót érdemli meg!"21

${ }_{17}$ Pukánszky Béláné, Kádár Jolán levélváltása Némedi Lajossal.

${ }^{18}$ Debrecen irodalmi társaságai a 20. század első felében - fóként a Csokonai Kör és az Ady Társaság - nagyon fontos szerepet játszottak a város és egész Magyarország közéletében. Tagjaik - köztük Pukánszky Béla -, vezető tisztségviselőik egymással szorosan együttműködve adták a korszak vezető értelmiségét. Szinte kivétel nélkül ugyanazok a személyek - kutatásom föszereplői - jelentek meg ezekben a szervezetekben. Közszerepléseiket legtöbben szabadidejükben, kedvtelésből tették, hiszen foállásuk a Debreceni Tudományegyetem bölcsész tanszékeihez kötötte őket. Egyetemi vezetőként, országos, sőt nemzetközi hírü tudósként élték mindennapjaikat, hủen szolgálva a tudományos és kulturális-művészeti életet. Az Ady Társaságnak nemcsak az irodalmi, hanem a képzőművészeti osztálya is maradandó hatást gyakorolt a korabeli közönségre, hiszen tagjai elsőként csoportosultak a provinciális akadémizmussal szemben, tehát tevékenységük jóval túlmutatott egy vidéki egyesület müködésén. Vö. Tamusné Molnár, Müvészeti nevelés az egyetem falai között és azon túl.

19 JuHÁsz Izabella, A debreceni Ady Társaság bibliográfiája (1927-1951) (Debrecen: KLTE Könyvtára, 1977).

${ }^{20}$ PukÁnszky, „Bartók Béla”.

${ }^{21}$ Straky Tibor, „Debrecen zenei élete 1944-1990”, in Debrecen története 5. Tanulmányok Debrecen 1944 utáni történetéböl, szerk. Veress Géza (Debrecen: Csokonai Kiadó, 1997), 245. 
Az új közönség nevelési tendenciája érvényesült az 1948-49-ben tartott Mesterbérlet-sorozat 10 hangversenyének előzetes ismertetésében is. ${ }^{22}$ Ezekben az években rendszeresen folytatta ismeretterjesztő tevékenységét a Déri Múzeumban, üzemekben (pl. a vagongyári előadása Beethovenről), a zsidó hitközségben (Thomas Mann Józseftetralógiájáról) és a Zeneiskola hangversenyein. ${ }^{23}$

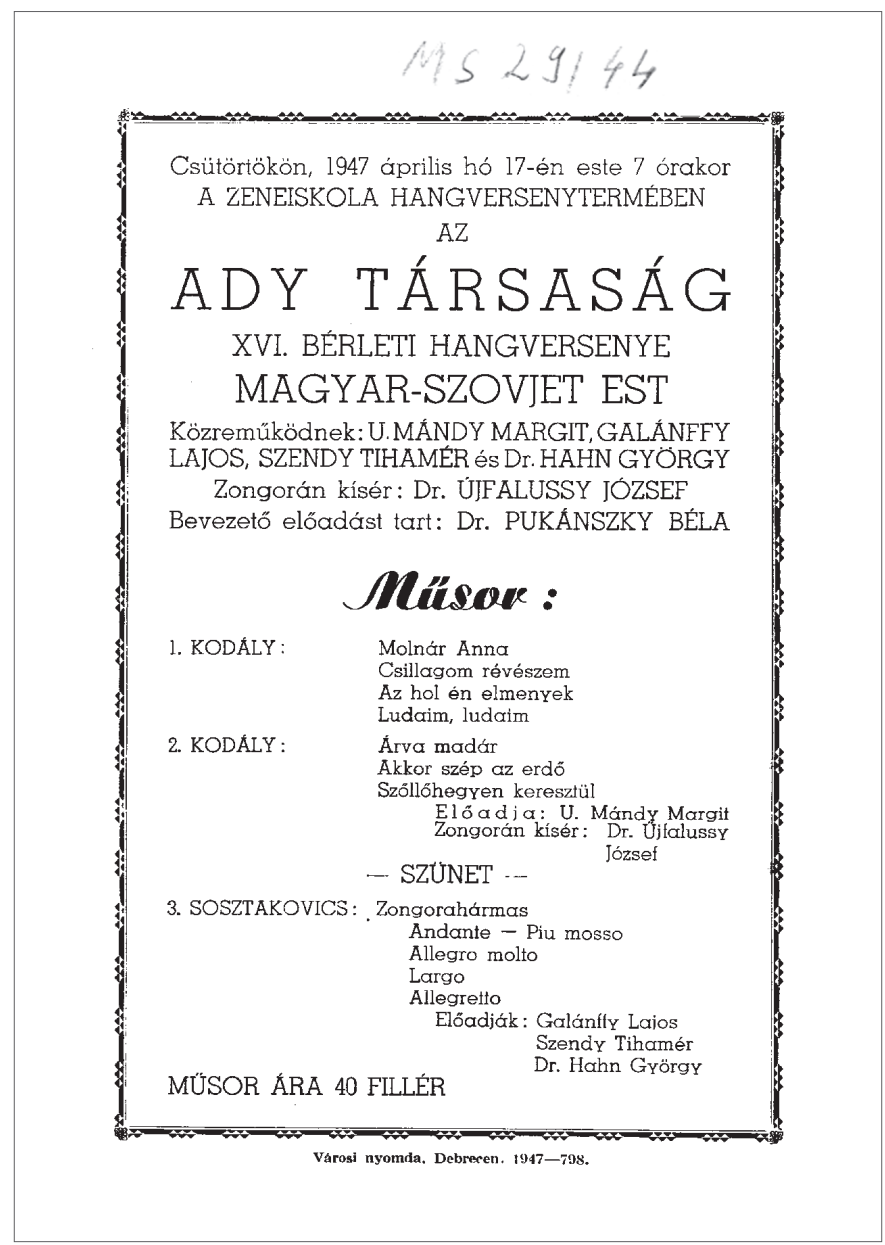

1. kép. Az Ady Társaság egyik bérleti hangversenyének meghivója Pukánszky Béla bevezetö elöadásával, 1947

Forrás: Pukánszky Béla bevezető zenetörténeti előadásai az Ady Társaság hangversenyei előtt.

DEENK Kézirattári Különgyűjteménye, Ms. 29/44.

${ }^{22}$ Uo., 244

${ }^{23}$ PUKÁNSZKY Béla-anyag; PukÁnszKy Béla bevezetö zenetörténeti elöadásai az Ady Társaság hangversenyei elött (1946-1947). DE ENK BTK és TTK Kt. kgy. Ms. 29/39g/3. 


\section{Pukánszky Béla zeneelméleti, -történeti és elöadói jelentösége}

Pukánszky Béla Debrecen, Budapest és egész Magyarország művészeti közéletében aktív szerepet vállalt művészetekkel foglalkozó tudományos és ismeretterjesztő írói, illetve előadói tevékenységével. A debreceni egyetemen és a közéletben betöltött szerepei számtalan alkalmat biztosítottak a nyilvánosság előtti szereplésre - tanártársaihoz hasonlóan. ${ }^{24} \mathrm{Az}$ ország és a város vezető sajtóorgánumaiban számos publikációja jelent meg. Elsősorban zenei és irodalmi seregszemléken, baráti összejöveteleken, a Magyar Rádióban, a Magyar Állami Operaházban, a Déri Múzeumban, a Csokonai Színházban, a Debreceni Nyári Egyetem eseményein és az Ady Társaság nyilvános rendezvényein vállalta népszerüsítő előadások tartását. Leginkább rendszeresen jelentkező müvészeti kritikáival vált ismertté a lakosság körében. Zeneművek ismertetésével népszerüsítette a klasszikus zene- és operairodalom kiemelkedő, gyakran játszott alkotásait a hangversenytermek közönsége számára. A hazai kulturális-művészeti élet tevékeny közreműködője volt hosszú éveken át képzett zongorajátékával és zenetörténeti előadásaival.

${ }^{24}$ A doktori értekezésben feltárt tanári életpályák jellemzője, hogy szinte minden művészeti ággal kapcsolatot tartottak. Akár helyben éltek, akár más városból érkeztek Debrecenbe, előbb-utóbb tagjai lettek a város értelmiségi köreit tömörítő szervezeteknek, sőt ezek vezető testületét, elitét alkották gyakran több társaságban egyszerre. Buzgó publicisztikai, tudományos ismeretterjesztő előadói és műalkotásokat kiállító szerepvállalásuk fontos szerepet töltött be Debrecen kulturális életében, ami jelentős fejlesztő hatást gyakorolt a „maradandóság városára”, ahol a kortárs művészeti élet iránti érdeklődés erősen mérsékelt jellegü (volt). Vö. Tamusné MolnáR, Müvészeti nevelés az egyetem falai között és azon túl. Továbbá VINCZE Tamás, „Mitrovics Gyula egyetemi és egyetemen kívüli szerepvállalása, közéleti funkciói”, in A „Debreceni Iskola” neveléstudomány-történeti vázlata, szerk. BREZSNYÁNsZKY László (Budapest: Gondolat Kiadó, 2007), 128-139; Uö, Karrierutak és iskolateremtés a XX. század elsö felének magyar neveléstudományában (Mitrovics Gyula pályájának és szakmai mühelyének kvalifikációtörténeti nézöpontú bemutatása). Doktori (PhD) értekezés. DE BTK Humán Tudományok Doktori Iskolája. (Debrecen, 2011.) https://dea.lib.unideb.hu/dea/bitstream/handle/2437/109275/Vincze\%20 Tam\%C3\%A1s\%20doktori\%20\%C3\%A9rtekez\%C3\%A9se-t.pdf?sequence=6\&isAllowed=y. Hozzáférés: 2015. 03. 15. 